25. Korreljacija reakcionnoj sposobnosti jelementoorganicheskih hloridov $\mathrm{v}$ reakcii okislenija metallov $\mathrm{v}$ aprotonnyh sredah / S. V. Panteleev, S. V. Maslennikov, A. N. Egorochkin, I. V. Spirina // Zhurnal obshhej himii. - 2007. - T. 77. - Vyp. 7. - P. 1072-1074.

26. Kuprin V. P. Adsorbcija organicheskih soedinenij na tverdoj poverhnosti / V. P. Kuprin, A. B. Shherbakov. - Kiev: Naukova dumka, 1996. -162 p.

27. Kuprin Vitalij Pavlovich. Izbiratel'naja adsorbcija organicheskih veshhestv na metallah i podgotovka poverhnosti pered naneseniem pokrytij : dis. Dokt. Him. Nauk : 02.00.05/ Kuprin Vitalij Pavlovich. Dnepropetrovsk, 1993. -323 p.

28. Pal'm V. A. Osnovy kolichestvennoj teorii organicheskih reakcij / V. A. Pal'm. - L.: Himija, 1977. - 360 p. 29. Doslidzhennja trybohimichnoi' systemy «bronza BrAZh 9-4-tioamid-olyva I-20A - stal' 45» / [O. A. Gordienko, N. O. Didenko, T. S. Titov ta in.] // Problemy trybologii'. - 2018. - T. 88, № 2. - P. 89-93. 30. Himija tioamidov. Soobshhenie III. Sintez i issledovanie nekotoryh tioamidov kak prisadok k smazochnym materialam / A. P. Ranskiy, I. G. Ploshenko, A. G. Panasjuk, M. Ju. Vakulenko // Voprosy himii i himicheskoj tehnologii. - 2003. - № 4. - P. 150-153.

31. Himija tioamidov. Soobshhenie IV. Aril- i alkilamidy benztiazol-2-tiokarbonovoj kisloty kak prisadki k smazochnym maslam / A. P. Ranskiy, I. G. Ploshenko, A. G. Panasjuk, M. Ju. Vakulenko // Voprosy himii i himicheskoj tehnologii. - 2003. - № 6. - P. 177-181.

32. Ranskiy A. P. Himija tiamidov. Soobshhenie V. Alkil-, arilamidy benzimidazol-2-tiokarbonovoj kisloty kak prisadki k smazochnym maslam / A. P. Ranskiy, I. G. Ploshenko, A. G. Panasjuk // Voprosy himii i himicheskoj tehnologii. - 2004. - № 4. - P. 42-46.

33. Ranskiy A. P. Himija tioamidov. Soobshhenie VI. Addukty N-alkil-N-ariltio $\neg$ amidov $\mathrm{s}$ galogenkarbonovymi kislotami kak prisadki k industrial'nym maslam / A. P. Ranskiy, A. G. Panasjuk, M. V. Kuchuk // Voprosy himii i himicheskoj tehnologii. - 2005. - № 2. - P. 139-141.

34. Ranskiy A. P. Himija tioamidov. Soobshhenie VIII. Smeshannoligandnye kompleksy medi(II) arilamidov benzimidazol-2-tiokarbonovoj kisloty kak prisadki k smazochnym maslam / A. P. Ranskiy, A. G. Panasjuk // Voprosy himii i himicheskoj tehnologii. - 2005. - № 2. - P. 42-45.

35. Ranskiy A. P. Himija tioamidov. Soobshhenie H. Sintez mednyh kompleksov alkilamidov benzimidazol-2tio $\neg$ karbonovoj i galogensoderzhashhih kislot $\mathrm{i}$ ih issledovanie kak prisadok $\mathrm{k}$ smazochnym maslam / A. P. Ranskiy, A. G. Panasjuk, A. A. Mitrohin // Voprosy himii i himicheskoj tehnologii. - 2006. - № 4. - P. 36-41.

36. A. s. 1409643 A1 SSSR, MKI S07M141/08. Smazochnaja kompozicija / B. A. Bovykin, I. G. Ploshenko, A. P. Ranskiy, A. A. Mitrohin, A. Ja. Shtan'ko, S. P. Suhovoj, V. D. Sedleckij. - zajavl. 26.02.1986 ; opubl. 15.07.1988, Bjul. № 26.

DOI: doi.org/10.18372/38220

UDC: $629.063 .6-028.82(045)$

\title{
2.3 DEVELOPMENT OF ALTERNATIVE JET FUELS MODIFIED WITH CAMELINA OIL BIO-ADDITIVES
}

\author{
Anna Iakovlieva ${ }^{1}$, Sergii Boichenko ${ }^{2}$, Kazimierz Lejda ${ }^{2}$, Hubert Kuszewski ${ }^{2}$, Oksana Vovk ${ }^{1}$
}

Constant increase of aircraft fleet and exhausting crude oil deposits promote worsening of the world energy crisis. As a result we observe rise in prices for jet fuel (JF) that today comprise about $25-30 \%$ of passenger travel [1]. Moreover, products of fuel combustion cause detrimental impact on environment. Thus, the task of search and development of alternative JFs became especially important.

This work is devoted to the study of possibilities of partial replacement of conventional JFs with components of biological (plant) origin. It will allow decreasing the dependence on exhaustible energy sources and minimizing negative impact of aviation on environment.

Today alternative fuels from various renewable feedstock are actively developed and studied. Among them are fuels made of biomass, plant oils, animal fats, microalgae, waste from agriculture, wood processing industry, municipal waste etc [2]. JFs produced from biomass via FT- 
synthesis and fats hydration were successfully tested and now are already implemented [3]. Theses alternative fuels possesss high quality, however its' chemical structure looks as completely synthetic paraffinic kerosene [5]. It means that entering the environment fuel causes negative impact on nature similarly to conventional JFs.

There is a good experience in use of conventional JF mixture with bio-additives produced from plants oil up to $50 \%$ [6]. These bio-additives are methyl or ethyl esters of plant oils or animal fats. The most rational feedstock is rapeseed or camellina oils (CamO) [7]. Camelina relates to energy crops with high oil content. The main consumers are the producers of biofuels. Camelina is used in agriculture as crop rotation, which prevents reduction of soil fertility and provides increasing of crop resistance to diseases and pests. It is not demanding to climatic conditions and does not require substantial cultivation and care. Camelina seeds contain $40-50 \%$ of oil, providing oil output of about $1250 \mathrm{l} / \mathrm{ha}$ [1-5]. Another advantage of this culture is the use of meal as feed for livestock and poultry. The scientists believe these camelina characteristics provide "sustainability" of the process of aviation biofuels production without creating competition in the food industry. Nowadays this culture is widespread in the US, Canada and some European countries [2].

However, today application of these bio-additives as components of JF is at the early stage of development and need to be studied completely. In this regards, the work is devoted to studying persectives of development new alternative JFs with CamO bio-additives.

The purpose of this work is to study key physical-chemical and exploitation properties of JFs modified with CamO bio-additives and to consider the possibility of using JF, blended with bio-additives in aircrafts' jet engines.

In order to reach the set purpose it was necessary to fulfill the next tasks:

- To study experimentally the main physical-chemical and exploitation properties of JF and CamO bio-additive;

- To study experimentally the main physical-chemical and exploitation properties of JFs modified with CamO bio-additives in quantity $10 \%, 20 \%, 30 \%, 40 \%$ and $50 \%$;

- To analyze and explain the influence of bio-additives on physical chemical and exploitation properties of JFs.

The quality of fuel samples was determined according to the following physical-chemical and exploitation properties: density, fractional composition, heat of combustion, kinematic viscosity, freezing point, anti-wear properties, fire safety and corrosiveness. The mentioned properties are considered to be identifying for quality control of conventional and blended JFs.

For fulfilling experimental studies conventional JF of grade Jet A-1 was used. This type of fuels was produced by Polski Koncern Naftowy «ORLEN» (Plok, Poland), and its quality parameters meet requirements of specifications ASTM D1655, Def Stan 91-91.

For obtaining alternative JF CamO fatty acids ethyl esters (FAEE) bio-additive were used. It was produced in the Institute of bioorganic chemistry and petrochemistry of the National Academy of Sciences of Ukraine.

Within the scope of the work physical-chemical and exploitation properties of pure JF, pure sample of bio-additive and JF blends, which contained $10 \%, 20 \%, 30 \%, 40 \%$ and $50 \%$ of bioadditive were studied. The list of studied fuel samples and its designations are presented in Table 1.

Physical-chemical and exploitation properties of JF, bio-additives and JFs blended with bioadditives were studied using standard methods and equipment based in the Laboratory of Exploitation Materials at the Department of Internal Combustion Engines and Transport of Rzeszow University of technology and in the Laboratory "Aviatest" of the Scientific-Research Center of Chemmotology and Certification of Fuels, Lubricants and Technical Liquids of the National Aviation University. Density (denoted as $\rho$ ) was estimated according to ASTMD4052 using device for density determination "AntonPaar", DMA 4500M. Density was determined at temperature $15{ }^{\circ} \mathrm{C}$ that is specified by ASTM D1655. Fractional composition was determined according D86 using automatical fractional composition analyzer "Herzog Optidist". 
Description of fuels samples used for studying physical-chemical and exploitation properties

\begin{tabular}{|l|l|l|}
\hline No & Sample description & Sample designation \\
\hline 1 & Jet fuel of grade Jet A-1 & JF \\
\hline 2 & Bio-additive - fatty acids ethyl esters of camelina oil & CamO FAEE \\
\hline 3 & Jet fuel blended with $10 \%$ of bio-additive & $\mathrm{JF}+10 \%$ CamO FAEE \\
\hline 4 & Jet fuel blended with $20 \%$ of bio-additive & $\mathrm{JF}+20 \%$ CamO FAEE \\
\hline 5 & Jet fuel blended with $30 \%$ of bio-additive & $\mathrm{JF}+30 \%$ CamO FAEE \\
\hline 6 & Jet fuel blended with $40 \%$ of bio-additive & $\mathrm{JF}+40 \%$ CamO FAEE \\
\hline 7 & Jet fuel blended with $50 \%$ of bio-additive & $\mathrm{JF}+50 \%$ CamO FAEE \\
\hline
\end{tabular}

Viscosity (denoted as $v$ ) was determined according to ASTMD445 using automatic device for viscosity determination "HerzogLow temperature viscometer", HVU 482. Viscosity was determined at temperature $-20{ }^{\circ} \mathrm{C}$ that is specified by ASTM D1655 and also in a temperature range from $-20{ }^{\circ} \mathrm{C}$ to $100{ }^{\circ} \mathrm{C}$. Heat of combustion (denoted as Q) was determined according to ASTM using Automated Bomb Calorimeter IKA C 200 produced by IKA Werke GmbH\&Co. KG. Flash point (denoted as $t_{\mathrm{fl}}$ ) was determined according to ASTM D93 using Pensky-Martens Flash Point Analyzer HFP 339 (produced by Walter Herzog. Corrosiveness was determined according to ASTM using Analyzer for Corrosion Testing of Fuel (also LPG) To Copper produced by ANKO. Freezing point (denoted as $t_{\mathrm{f}}$ ) was determined according to ГОСТ 5066-91 (ИСО 3013-74) using Petroleum products low-temperature properties analyzer UTF 70 produced by Crioholod. Antiwear properties were investigated using a T-02U four-ball tester by means of determining the scuffing load applied to the friction pair of the tester. The rotation speed during tests was $500 \mathrm{rpm}$, with the load increase rate of $409 \mathrm{~N} / \mathrm{s}$. The initial temperature of the fuel sample at the start of the test run was $20 \pm 1.0^{\circ} \mathrm{C}$.

Today there are strict requirements to JFs connected with efficiency, reliability durability of aircraft equipment and environmental safety $[1,2,7]$. Among the general technical requirements special attention should be paid to:

- High level of evaporability that provides reliable flammability and completeness of fuels combustion;

- Good low temperature properties, which provide reliable fuel pumpability at low temperatures;

- Chemical and thermal stability with minimal tendency to form deposits in the fuel system of theair craftengine;

- Absence of negative impact on metal and non-metal parts of the engine fuel system, equipment for fuel storage and transportation;

- Good lubricating properties thate liminate excessive wearing of fuel assemblies friction parts;

- The optimal level of electrical conductivity, which excludes fuel electrification and provides safe fuel transfer and filling of fuel tanks;

- Absence of toxic components, impurities and additives, minimum content of sulphur compounds, which lead to harmful products in there sultof fuel combustion. 
This complex of requirements is provided by physical-chemical, exploitation and ecological properties of jet-fuels, which are determined by nature and properties of raw material, methods of basic fractions productions, methods of their purification and mixing, additive sapplied [3].

At thef irst stage of the work we were studying physical-chemical properties of conventional JF Jet A-1 and CamO FAEE bio-additive. Characteristics of conventional JF and bio-additive are presented in Table 2 .

It is seen from the table that properties of conventional JF completely meet the requirements of standard. However, bio-additive differs from properties of JF. Next, the compatibility of bioadditive with conventional JF and its influence on key physical chemical and exploitation properties of modified JF were studied.

Table 2

Physical-chemical properties of conventional jet fuel and biocomponents

\begin{tabular}{|c|c|c|c|c|}
\hline $\mathrm{N}$ & Property & ASTM D1655 & Jet fuelJetA-1 & CamO FAEE \\
\hline 1 & Density at temperature $15^{\circ} \mathrm{C}, \mathrm{kg} / \mathrm{m} 3$ & $775-840$ & 794.03 & 874.49 \\
\hline 2 & $\begin{array}{l}\text { Fractional composition }{ }^{\circ} \mathrm{C} \text { : } \\
\text { - } 10 \% \text { distilled at temperature } \\
\text { - } 50 \% \text { distilled at temperature } \\
\text { - } 90 \% \text { distilled at temperature } \\
\text { - final boiling point }\end{array}$ & $\begin{array}{l}\max 205 \\
\text { max registered } \\
\text { max registered } \\
\max 300\end{array}$ & $\begin{array}{l}169.15 \\
186.2 \\
217.13 \\
243.44\end{array}$ & - \\
\hline 3 & $\begin{array}{l}\text { Kinematic viscosity, } \mathrm{mm}^{2} / \mathrm{s}: \\
\text { - at minus } 20^{\circ} \mathrm{C} \\
\text { - at } 20^{\circ} \mathrm{C}\end{array}$ & $\begin{array}{l}\max 8.0 \\
-\end{array}$ & $\begin{array}{l}3.2923 \\
1.5004\end{array}$ & $\begin{array}{l}16.413(-10) \\
6.422\end{array}$ \\
\hline 4 & Freezing point, ${ }^{\circ} \mathrm{C}$ & $\max$ minus 47 & minus 57 & minus7 \\
\hline 5 & Flash point, ${ }^{\circ} \mathrm{C}$ & $\min 38$ & 43 & 35 \\
\hline 6 & Higher heat of combustion, $\mathrm{kJ} / \mathrm{kg}$ & - & 46368 & 39842 \\
\hline 7 & Copper strip test & 1 & $1 \mathrm{a}$ & $1 b$ \\
\hline 8 & $\begin{array}{l}\text { Lubricity: } \\
\text { Scuffing load, N }\end{array}$ & - & 523 & 2644 \\
\hline
\end{tabular}

Density. The density $\rho$ of JFs is one of its main physical characteristics that influences directly on the flammability of fuel: the processes of evaporation, fuel-air mixture formation, completeness of combustion and fuel flow of the aircraft. The required density of JFs ensures reliable operation of fuel system of JE $[4,8]$.

The density of the JFs depends on its chemical and fractional composition. The increase of heavy fractions, aromatic hydrocarbons and reduction of paraffinic hydrocarbons contribute to increasing fuel density [8].

Fuel density plays an important role for evaluation its energy properties, including energy value and heat of combustion. Increase of aromatic hydrocarbons content in JF leads to increase of density and to rise of fuel boiling point, and as a result, increase of JF energy value [9].

The density of the JFs depends on its chemical and fractional composition [4]. CamOFAEE bio-additivepossesses much higher density value comparing to conventional JF (Table 2). It can be 
explained by its chemical structure. Unlike hydrocarbons of conventional JFs, which contain $5 \div 16$ carbon atoms, acyl radicals of ester molecules contain on average $15 \div 26$ carbon atoms [4]. This is the reason of a strong dispersion interaction forces between them and, consequently, higher density compared to JFs.

According to the research of bio-additives samples impact on JFs' density (Fig. 1), it was found that density dependence is additive in nature and may be depicted as a straight line.

Density of blended JFs increases with increasing content of bio-additives, which happens due to strengthening of the dispersion forces of interaction between molecules of hydrocarbons and acyl radicals of esters on one hand, and the appearance of induction force of interaction between hydrocarbons of JF and carboxylic groups of esters on the other [3, 4, 9].

It is known that JFs of greater density and higher final boiling point were developed in order to improve the energy properties of JFs, mainly its energy content, [6]. However, this was limited by negative impact on fuel evaporability and their low-temperature properties. It can be assumed that the addition of bio-additives to JFs will expand the range of boiling points also. Thus, the next step is to study the fractional composition of JFs blended with bio-additives.

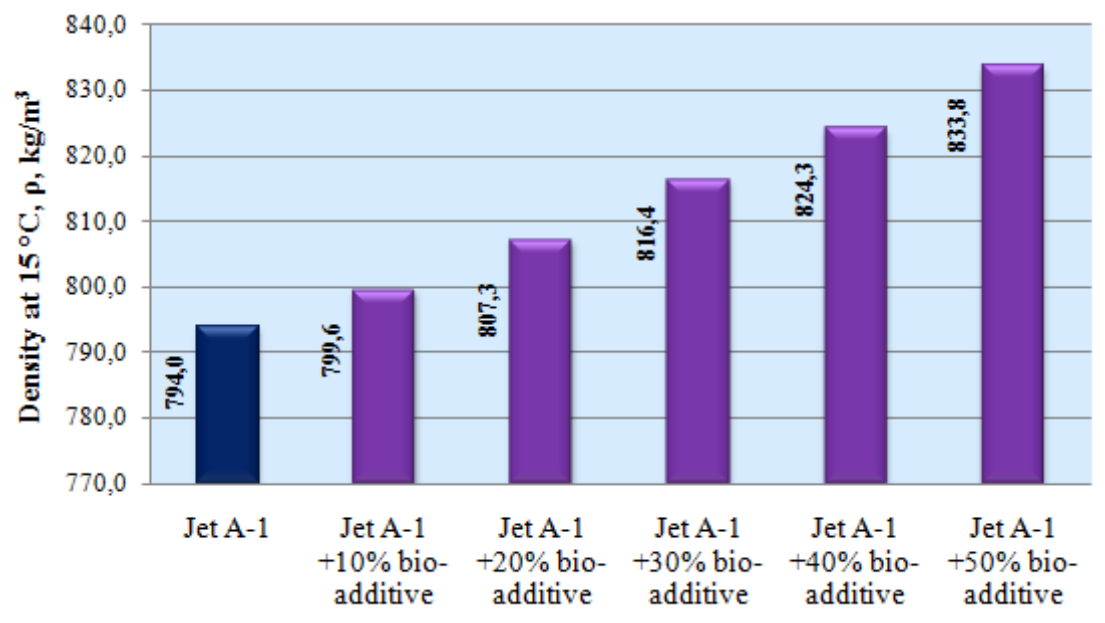

Fig. 1. Density of tested fuel samples with CamO bio-additive at $t 15^{\circ} \mathrm{C}$

Fractional composition. JFs are a mixture of hydrocarbons of various structures [2, 7]. The data on JF's fractional composition allow evaluating the exploitation properties of JF and operation of the aircraft's fuel system: fuel evaporability, tendency to vapor locks, completeness of fuel combustion, absence of smoke and carbon inside the combustion chamber [8,9].

Since bio-additives are also a mixture of organic compounds, a range of boiling points is also typical for it $[2,4,5]$. They belong to another class of organic compounds, which differ from petroleum hydrocarbons and from each other by structure, molecular weight and boiling points [5, $8]$.

Next, the influence of bio-additives on fractional composition of JFs was studied (Fig. 2). Fuel samples containing CamO FAEE in JF of grade Jet A-1 in quantities of $10 \%, 20 \%, 30 \%$, $40 \%$ and $50 \%(\mathrm{v} / \mathrm{v})$ were studied.

The graph shows that blending JF with bio-additives affects its fractional composition, extending toward the final boiling point. Increasing of boiling points of modified JFs is explained by much stronger intermolecular bonds between esters molecules and higher heat of evaporation values of ester consequently: $58.6-69.3 \mathrm{~kJ} / \mathrm{mol}$ for FAEE comparing to JF's hydrocarbon $31-47$ $\mathrm{kJ} / \mathrm{mol}$. 
From the graph it may be seen that boiling of fuel samples starts at about $76-77{ }^{\circ} \mathrm{C}$. This means that CamO bio-additive contains some amount of ethanol that left in esters mixture after production process. Analyzing the data on the graph it may be concluded that the content of ethanol is up to $5-7 \%$ The final boiling points of fuel sample are about $347-350{ }^{\circ} \mathrm{C}$, which are similar to final boiling points of pure bio-additives.

Widening of the fractional composition in a result of JF modification with esters, mainly towards the final boil point ensures reduction of light fractions, thus reducing its evaporabiity. This in turn will reduce fuel losses from evaporation, reduce the possibility of vapor locks formation of and improve its fire safety.

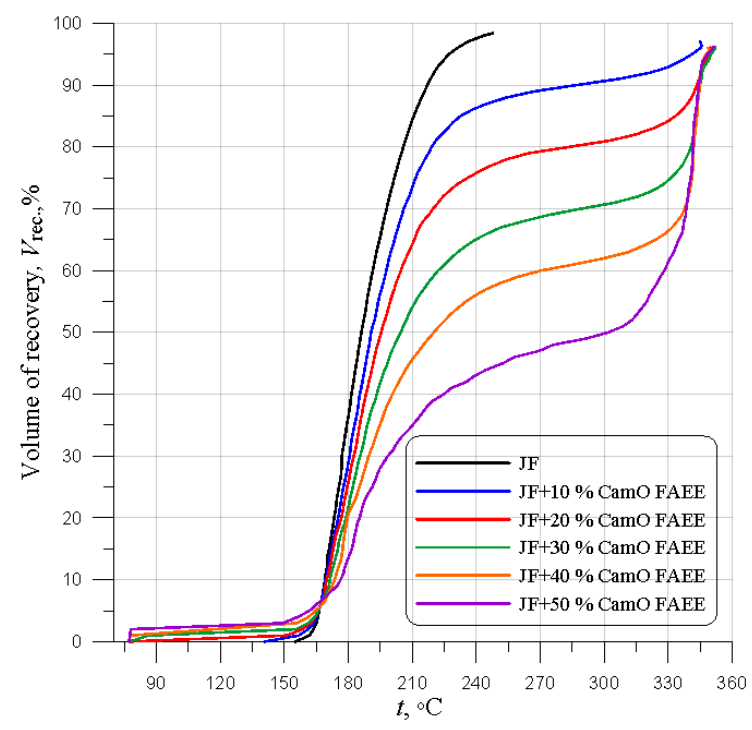

Fig. 2. Fractional composition of JF of grade Jet A-1 blended with CamO FAEE

However, the lighter fraction composition and higher vapor pressure, the better starting properties of JFs. Thus, fuels with high evaporability are able to provide jet engine launch with poor fuel-air mixture comparing to fuels with lower evaporability. In addition, increased volatility of fuels contributes to the increase of completeness of combustion and reduction of carbon formation in combustion chambers [4, 6, 9]. Studies of modified JFs showed that initial boiling point and temperature of $10 \%$ (vol.) of recovery, which characterize evaporability and starting properties of JFs are within the values, which are set by specifications for JF of grade Jet A-1. Thus, the use of blended fuels should not have a negative impact on the launch of JEs. The final boiling point of modified JFs (up to $350{ }^{\circ} \mathrm{C}$ ) significantly exceeds the norms established by specifications (up to $300{ }^{\circ} \mathrm{C}$ ). This heavy fractional composition due to increased density of blended JFs will increase their energy value.

Energy properties. The heat of combustion is one of the most important physical and chemical parameters of JF quality that characterizes its energy properties $[5,6]$. The purpose of the fuel in the engine is converting its chemical energy into heat one for heating of air that entering the turbine and jet pipe of the aircraft $[4,9]$. For heating the required amount of air and obtaining the desired thrust characteristics of the engine it is better to use JF with the highest energy value.

According to specifications for JF the standard value is net heat of combustion. The heat of combustion is determined by its elemental composition: the more content of hydrogen in fuel, the higher is heat of combustion. Besides elemental composition, heat of combustion depends on the structure of fuel hydrocarbons. Thus, hydrocarbons of different structure have different energy of 
intramolecular bonds distruction. Among the components of JFs the maximal heat of combustion is typical for alkanes, then cyclic alkanes (naphtenes) and then aromatic hydrocarbons.

Data about the elemental composition of JF allows calculating its heat of combustion. Higher heat of combustion $Q_{\mathrm{h}}$ takes into account the heat of condensation of water vapors, which are formed during combustion. During the process of water condensation $2500 \mathrm{~kJ} / \mathrm{kg}$ of energy is released. It is known that heat of vapors condensation is not used during engine operation, so the lower heat of combustion $Q_{1}$ is used to characterize the fuel. Its value is less than higher heat of combustion on heat of water vapors condensation.

The method ASTM D4809 allows experimental determination of $Q_{\mathrm{h}}$ of fuel samples. Thus, within the scope of this work energy properties of fuel samples were estimated by the value of higher heat of combustion.

The results of measurements and calculations of heat of combustion of JF and CamO bioadditive are presented in Table 2. It is seen that heat of combustion of bio-additive is lower on about $6600 \mathrm{~kJ} / \mathrm{kg}$, that is explained by differences in elemental composition of bio-additive: esters contain $\sim 12 \%$ of hydrogen, while JF $-14 \%$. Esters contain $11-11.5 \%$ of oxygen, which almost absent in conventional JF.

Later the higher heat of combustion $Q_{\mathrm{h}}$ of JFs modified with bio-additives was investigated. It was found that blending of conventional JF with bio-additives reduces its higher heat of combustion (Fig. 3).

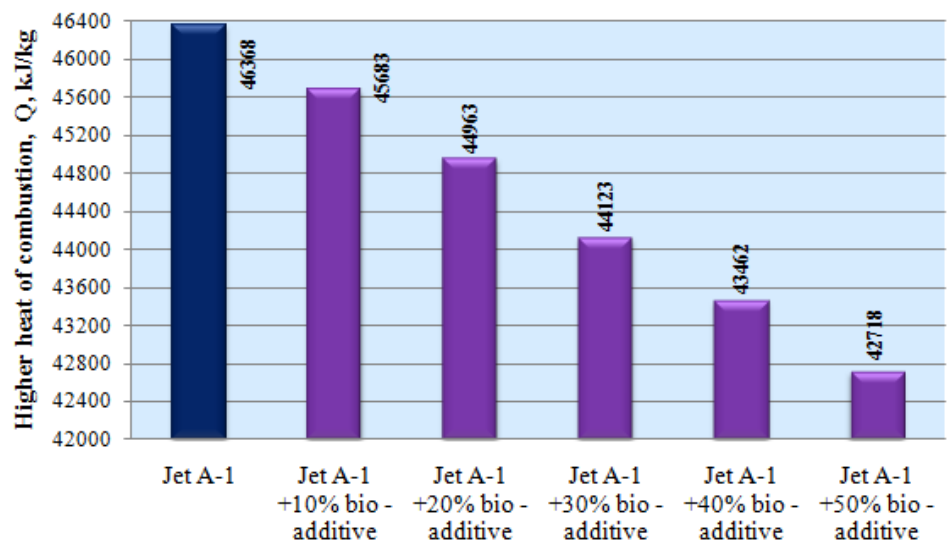

Fig. 3. Net heat of combustion of tested fuel samples

The results have shown that the blending JFs with bio-additives decreases its heat of combustion. Due to the fact that esters and blended JFs have higher density, it is reasonable to analyze in future works the changes in heat of combustion and energy value with increasing content of esters in JFs.

Kinematic viscosity. Stable operation of jet engine's fuel system at low temperatures largely depends on the fluidity of JFs that is measured by viscosity - a property of liquids to resist deformation of its volume by external forces. According to specifications for JF the standard value for describing viscosity is kinematic viscosity $\mathrm{v}, \mathrm{mm}^{2} / \mathrm{s}$.

The viscosity affects pumpability of JF within fuel system. Using high-viscous fuels can cause reduction of productivity of fuel pumps, reduction of injection pressure and quality of fuel spraying, especially at low temperatures $[3,6]$. This leads to the deterioration of JF volatility and completeness of combustion. Low viscosity is also undesirable. Fine dispersion of fuel causes local 
oversaturation of fuel-air mixture and narrowing range of the stable operation of combustion chamber. In addition, low viscosity values adversely affect the anti-wear properties of JFs [3].

Bio-additive based on FAEE of CamO is characterized by much higher viscosity values comparing to petroleum-derived JFs (Table 2).

The reason for this is chemical structure of bio-additives. Chain length determines the large size of the compounds, which leads to higher energy of intermolecular interaction [9]. Viscosity characterizes the strength of intermolecular interaction within the fuel $[1,2]$. The greater energy of intermolecular interaction, the greater is viscosity. It explains stronger dependence of esters' viscosity on temperature.

Viscosity-temperature dependence of esters can be explained by the fact that decreasing of temperature causes reduction of thermal energy of motion as well as mobility of molecules [3]. Temperature decrease leads to association increasing and rising of esters' viscosity. Hydrocarbon are characterized by smaller sizes and the energy of it's interaction is lower comparing to esters [3, 8].

CamO FAEE bioaditive possesses comparatively low viscosity values (if to copare with other types of bio-additives). Probably, this may be explained by the presence in bio-additive of small quantity of ethanol that possesses much smaller viscosity. Later the influence of CamO bioadditives on kinematic viscosity of modified JFs at $20^{\circ} \mathrm{C}$ was studied (Fig. 4).

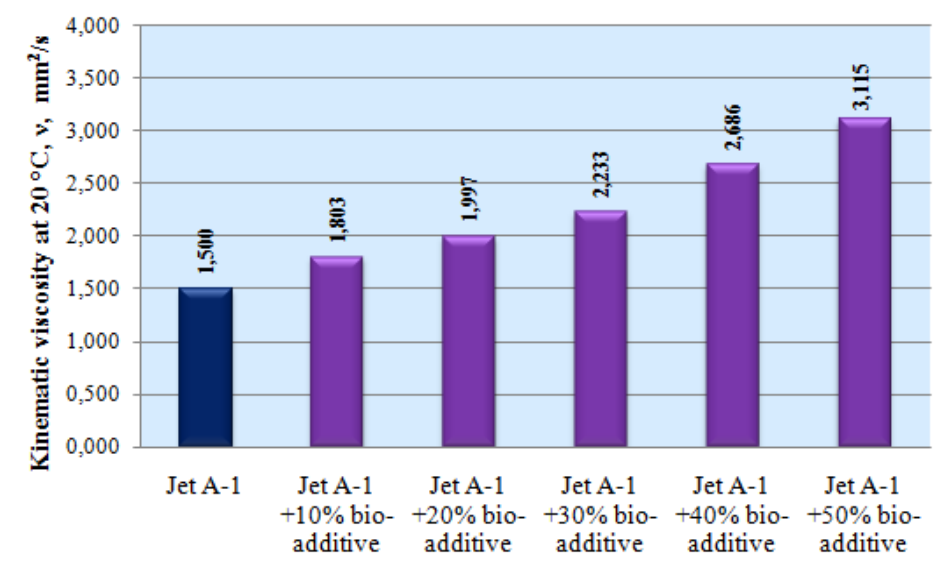

Fig. 4. Kinematic viscosity of tested fuel samples with CamO bio-additive at $20{ }^{\circ} \mathrm{C}$

It was found that blending of JFs with bio-additives causes increase of its kinematic viscosity. We suppose that this happens due to the appearance of forces of intermolecular interaction between JF's molecules and esters' molecules $[4,7]$.

Low-temperature properties. Low-temperature fuel properties of JFs are characterized by its behavior at low temperatures $[6,9]$ and are strictly controlled by specifications. During exploitation jet engines usually have to work at very low temperatures, especially in winter. In summer period fuel also can be cooled during high-altitude flights of subsonic jet aircrafts. The reason for this is that the ambient temperature at an altitude of 9-12 km reaches minus $50-70{ }^{\circ} \mathrm{C}[1,3]$. Cooling of JFs may be accompanied with clogging of fuel filters that may be associated with aircrafts accidents and disasters. Cooling of fuel also reduces spraying efficiency by fuel nozzles and worsening fuel pumps operation $[2,5]$.

Low-temperature properties of fuels are characterized by physical and chemical phenomena, which occur in fuels at temperatures below $0{ }^{\circ} \mathrm{C}$. Low temperature is a condition for occuring insoluble organic precipitates that affect fuel system operation. The reasons for its occurrence are 
the sharp decrease of solubility of some components in fuel at low temperatures and phase transitions $[2,7,8]$.

The main source of low-temperature precipitate in JFs is the crystallization of fuel's hydrocarbons when freezing point (FP) is reached. Decreasing of temperature causes crystallization of hydrocarbons, rise of crystals concentration and fuel gradually loses its fluidity and then freezes $[7,8]$.

Bio-additives based on FAEE of CamO are characterized by significantly higher values of FP comparing to JF (Table 2). High value of bio-additive's FP is stipulated by chemical structure of molecules and by Van der Waals interactions between them. The length of the hydrocarbon chains $\left(\mathrm{C}_{15} \div \mathrm{C}_{25}\right)$ defines the large size of the compounds. Due to this binding energy between molecules is higher comparing to conventional JFs [2, 3].

Due to the existence of intermolecular interaction forces the speed of random motion of esters molecules is insignificant. With temperature decrease its association is growing fast. Further temperature decrease causes viscosity rise to such a degree that esters freeze and loose mobility [8]. Presence of double bonds in esters makes them curve-shaped, that makes it difficult to locate compactly $[8,9]$.

The experimental results have shown that modifiying JFs with bio-additives increases its FP (Fig. 5). When concentrations of bio-additives are small, they are uniformly distributed in the volume of JF and distances between esters' molecules are not enough for interaction appearance. Further increase of esters content causes rise of FP that gradually approaches to values typical for pure esters.

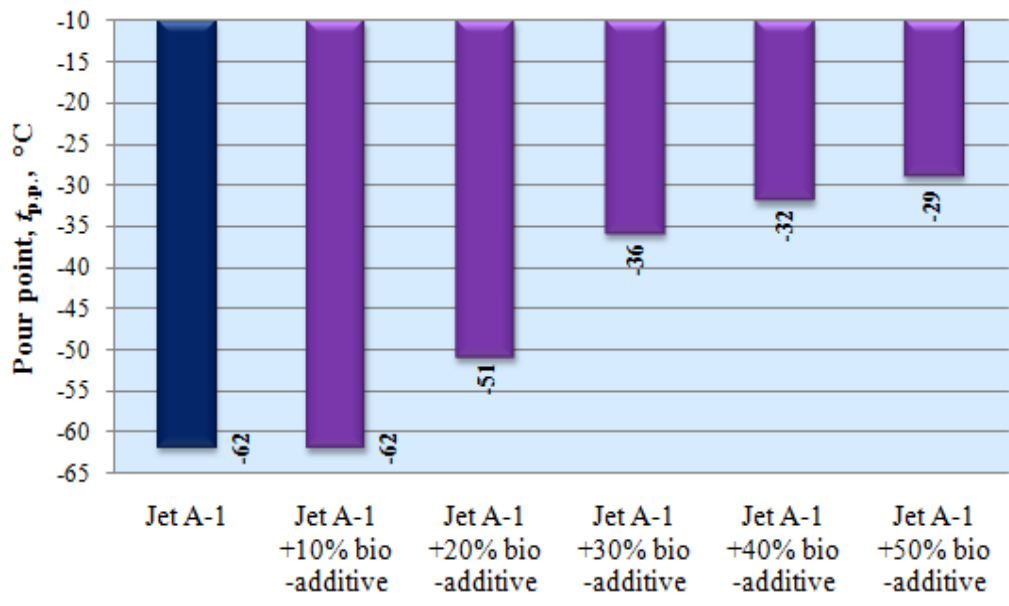

Fig. 5. PP of tested fuel samples with CamO bio-additive

When content of bio-additives in JF exceeds $30 \%$ the content of comparatively large esters molecules is sufficient for their associations due to attraction forces, and also due to the interlinking of molecules chains. A special role in the process of "interlinking" is played by unsaturated esters of curved form. Thus, associated esters' molecules initiate formation of structure within blended JFs. The other explanation of FP rise may be proposed: during temperature decrease small molecules of JF bond with single molecules or group of associated esters molecules. This promotes association of hydrocarbons and freezing of blended JFs.

Basing on the results of experiments we can make the conclusion that sample of modified JFs, which contain up to 20-25\% of CamO FAEE, satisfy requirements of specifications. 
From the studies [8] it is known that the reason for the decreasing of fuel pumpability at low temperatures is a significant increase in fuels' viscosity. In order to evaluate viscosity of modified JFs at low temperatures we have studied the mutual influence of temperature and concentration of bio-additives on the above mentioned property (Fig. 6).

Increasing the concentration of esters and reduction of the temperature are factors that contribute to the association of molecules of modified JFs primarily due to increasing the number of collisions (contacts) of esters' molecules. And reduction of temperature is a factor that strengthens the ties between associated molecules by reducing the speed of molecules thermal motion and, consequently, increases the viscosity and FP.

From the studies $[3,5]$ it is known that curves of JFs viscosity dependance on temperature change in the area of low temperatures very rapidly. Fig. 5 shows that even insignificant increase of temperature causes a significant decrease in fuels' viscosity. To avoid potential problems with blended JFs spraying at low temperatures it is possible to increase fuel pressure before the nozzles. This technical solution is well-known for a long time and has been successfully used during JEs exploitation. This allows achieving the required fineness of spraying and sufficient quality of fuelair moxture in the combustion chamber.

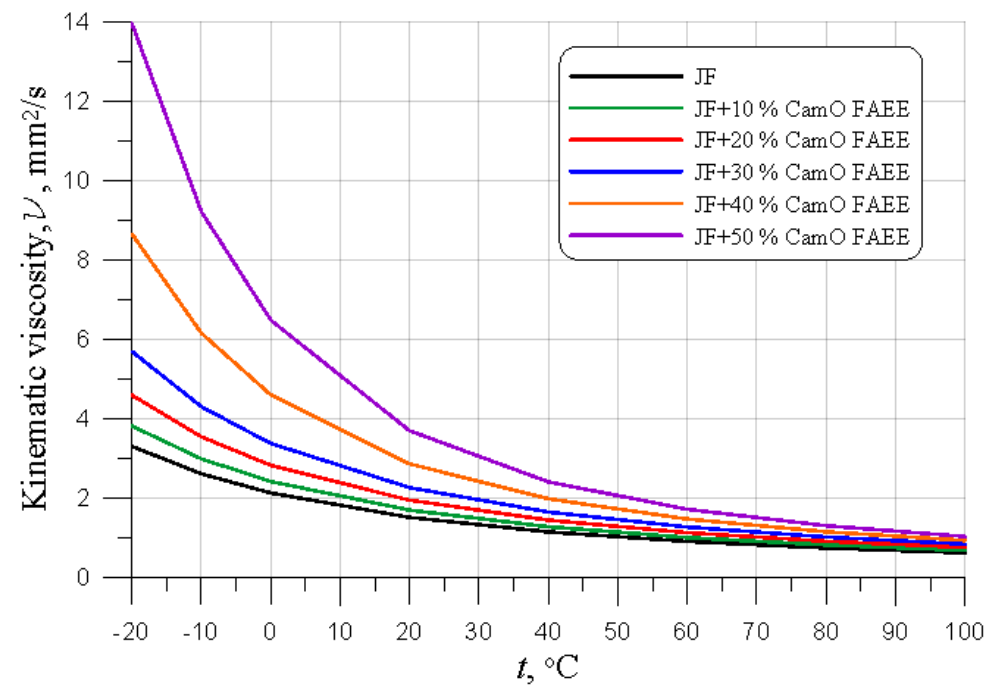

Fig. 6. Kinematic viscosity of tested fuel samples with CamO FAEE bio-additive asafunction of temperature

Anti-wear properties. It is known that antiwear properties of JFs determine reliability and operational life of aircrafts' fuel system equipment and friction pairs in particular [3, 7]. These pairs usually work in regimes of rolling friction, sliding friction and combined friction at various loads, temperatures, pressure, speed of relative movement [9]. At semi-liquid friction the antiwear properties of JFs are determined by:

- JF viscosity that provides hydrodynamic effect of wearing surfaces division by liquid,

- presence of surfactants in fuel that form high strength absorption layer at the wearing surface and divide surfaces with decreasing of friction coefficient and wearing details.

As it is noted in works [2, 3, 7] using of fatty acids esters positively influences on lubricating properties of fuels. The data in Table 2 shows that conventional JF's lubricity evaluated by the value of scuffing load $P_{\mathrm{S}}$ is significantly lower, comparing to CamO FAEE.

Surfactants in fuel cause its surface activity - ability of fuel or its components to absorb at the surface of metal, form the boundary film and thus prevent dry friction of details [2, 3, 7]. Fuel hydrocarbons almost do not protect friction pairs from wear. Substances, which are considered to 
be surface active, are gums, oxygen-, sulfur- and nitrogen-organic compounds. But presence of these substances is undesired, because of thermal stability and corrosion properties of fuel.

Fatty acids esters are natural surfactants. Presence of oxygen atom in carboxyl group in molecules stipulates strong polarity of esters. Such structure provides ability to absorb on surfaces of solid bodies and thus, ability to form polymolecular film - boundary layer. In a result of experimental data processing the dependence of scuffing load $P_{\mathrm{S}}$ of the friction pair in the medium of studied modified JFs on the content of bio-additives (Fig. 7) was obtained. In general obtained results indicate that increasing portion of bio-additives in modified JFs improves its antiwear properties [3].

Such view on lubricating properties of fatty acids esters allows us explaining obtained experimental results: gradual improvement of antiwear properties of JF with increasing content of bio-additives. During modifying JF with bio-additives the total content of surfactants in fuels rises. In a result the boundary film between friction pair become stronger. We can make a conclusion that blending conventional JFs with bio-additives improves its antiwear properties.

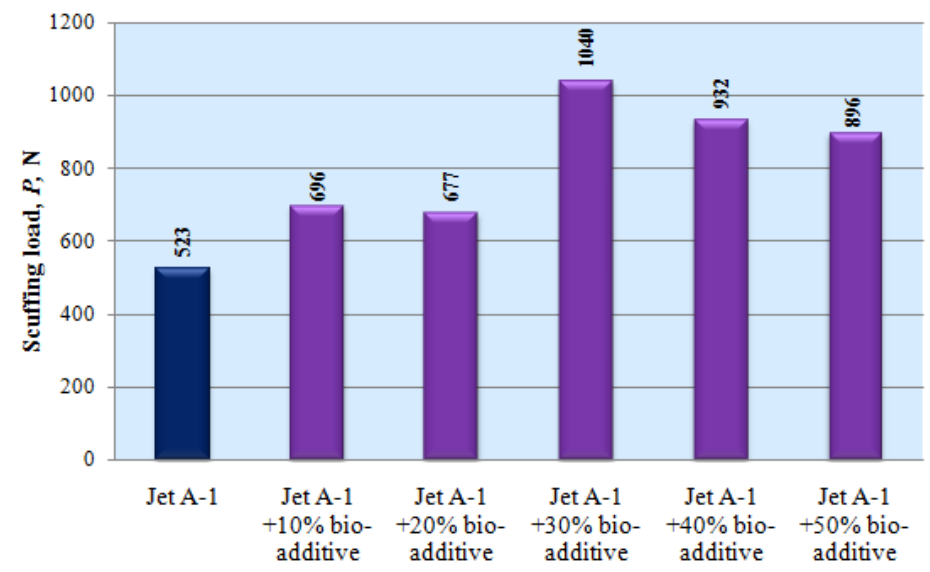

Fig. 7. Friction pair load in medium of tested fuel samples as a function of CamO bio-additives content

Fire safety. According to modern international specifications one of the dominant operational properties of JFs is its fire safety [7,8]. JFs belong to flammable liquids. They are characterized by high volatility, easy form a flammable mixture with air, during combustion form a large number of products of combustion and are good insulators. According to its fire safety JFs belong to hazardous liquids at high temperatures.

Traditionally fire safety of JFs is characterized by its flash point (FIP) $t_{\mathrm{fl}}$. This parameter shows the conditions under which the fuel becomes fire dangerous. Specifications for JFs regulate the lower limit of this parameter. Thus, the fuels of grade Jet A-1 should have FIP values, which are not lower than $38{ }^{\circ} \mathrm{C}$. According to experimental results of fire safety researches it was found that CamO FAEE is characterized by lower value of FIP comparing to conventional JFs (Table. 2). This result is explained by the presence of ethanol in bio-additive, left after the production process.

Corrosiveness. It is known that corrosivenessis one of the most important exploitation properties of JFs [3, 4]. It influences on durability, and reliability of jet engines. During exploitation details of fuel system equipment are the most subjected to corrosive influence of fuel; details of the jet engine's jet pipe are subjected to corrosive influence of fuel combustion products [8]. Corrosiveness is characterized by the presence of corrosively aggressive components in fuel. These components include sulfur and sulfur containing compounds, where the most aggressive are hydrogen sulfide and mercaptanes (thiols). Except that, the reasons of JFs corrosiveness are 
oxygen-containing heterogenic compounds, water-soluble alkalis and acids, dissolved oxygen and insoluble moisture $[4,6]$.

The process of chemical corrosion takes place during chemical interaction of corrosivelyactive substances, which are present in fuel, with color metals or their alloys that are used for producing details of aircrafts' fuel systems. The processes of corrosion are especially intensive when the water is present. The highest activity among sulfur compounds is typical for mercaptanes, elemental sulfur and hydrogen sulfide. Sulfides, disulfides, thiophenes and thiophanes are related to neutral sulfur compounds. However, at temperatures more than $120{ }^{\circ} \mathrm{C}$ these compounds decompose and form mercaptanes and hydrogen sulfide. Other words, they become corrosively active. Copper (bronze) alloys and steel details with coating (usually cadmium) are subjected to most intensive corrosion during exploitation.

Among JFs the highest corrosive activity is typical for fuels, which are produced from sulfur oils. Hydrogen sulfide is removed from fuels completely during crude oil processing. However, because of the technological reasons elemental sulfur and mercaptanes are still present in JFs is small quantities.

Corrosive action of JF sisrevealed at firstin destruction of copper surface; later significant corrosive sediments of black color appearon copper details. With time these sediments cut from surface and accumulate in fuel in the form of black in soluble particles, which cause clogging of filtering equipment. Corrosion of fuelling equipment, which are made of copper alloys, also depends on products of JF oxidation that are contained in fuel [4].

The method for JFs corrosiveness control is copper strip test. The degree of copper strip corrosion is estimated comparing to etalon sample (Fig. 8).

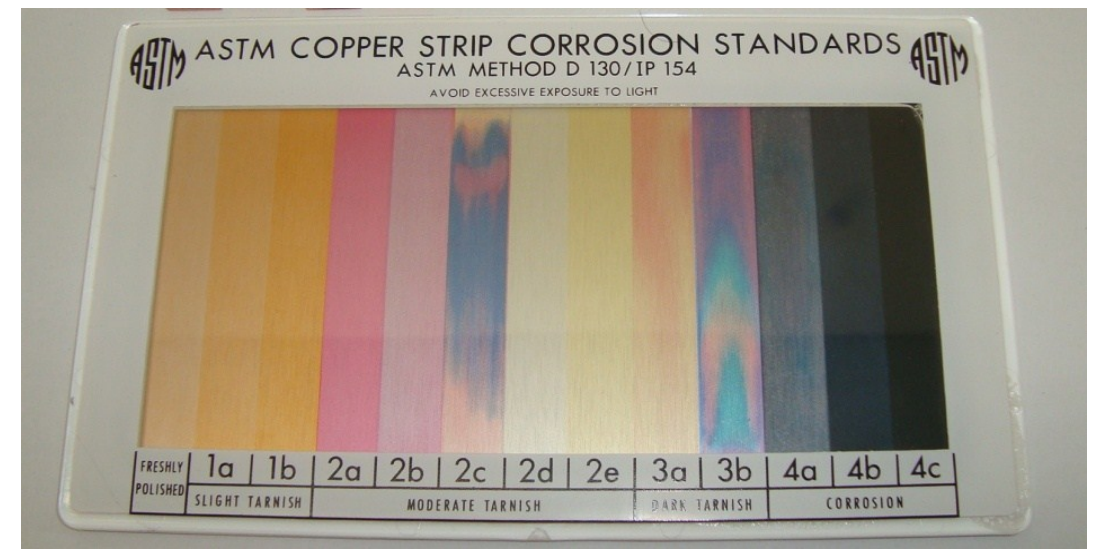

Fig. 8. The standard samples for determination copper strip corrosion

The results of tests of JF, bio-additives and samples of JFs blended with bio-additives on copper strip are presented in Table 3.

Table 3

The result of copper strip test of fuel samples

\begin{tabular}{|c|c|c|c|c|c|c|c|}
\hline Bio-additive & $\begin{array}{c}\text { JF of grade } \\
\text { Jet A-1 }\end{array}$ & $\begin{array}{c}100 \% \\
\text { bio- } \\
\text { additive }\end{array}$ & $\begin{array}{c}\mathrm{JF}+10 \% \\
\text { of bio- } \\
\text { additive }\end{array}$ & $\begin{array}{c}\mathrm{JF}+20 \% \\
\text { of bio- } \\
\text { additive }\end{array}$ & $\begin{array}{c}\mathrm{JF}+30 \% \\
\text { of bio- } \\
\text { additive }\end{array}$ & $\begin{array}{c}\mathrm{JF}+40 \% \\
\text { of bio- } \\
\text { additive }\end{array}$ & $\begin{array}{c}\mathrm{JF}+50 \% \\
\text { of bio- } \\
\text { additive }\end{array}$ \\
\hline CamO FAEE & $1 \mathrm{a}$ & $1 \mathrm{~b}$ & $1 \mathrm{a}$ & $1 \mathrm{a}$ & $1 \mathrm{a}$ & $1 \mathrm{~b}$ & $1 \mathrm{~b}$ \\
\hline
\end{tabular}


According to the requirements of ASTM and Def Stan specifications for JF of grade Jet A-1 the degree of copper strip corrosion have to be not more than 1 according to the scale on Fig. 8 . As we can see from the data in Table 3 the degree of corrosiveness of JFs modified with bioadditives completely satisfies requirements of existing specification.

This diversity of technologies provides the ability for JF production using various feedstocks. Scientists believe that the most promising feedstocks are plants with high oils content, algae and some types of industrial and household waste. This work was devoted to studying alternative JF produced by it modifying with CamO components.

In are sultof the work the complex of physical-chemical and exploitation properties and quality parameters of JF and Cam O esters were studied. The results have shown that the main characteristics of bio-additives differ from conventional JFs.

The dependencies of JF density, fractional composition, heat value, viscosity, freezing temperature and lubricity on the content of bio-additives were obtained. It is found that modification of JF with CamO esters results in increasing of fuel density and viscosity, rising of freezing temperature, decreasing of heating value and widening of fractional composition due to the rise of final boiling point. At the same time addition of CamO esters improves anti-wear properties of JFs. It was determined that jet fuel modification by biocomponents will have controversial effect on exploitation properties of new fuels. On one hand it may negatively influence on combustion process, and on the other hand it allows improving certain exploitation characteristics and making new JF more environmentally clean.

It may be concluded that modification of conventional JF by CamO bio-additives is possible. At the same time there is a need in more detailed influence of bio-additives on fuel properties for optimization of jet engines operation using new kind of fuel.

\section{PЕФЕРАТ \\ Анна Яковлєва ${ }^{1}$, Сергій Бойченко ${ }^{2}$, Казимир Лейда ${ }^{2}$, Хуберт Кужевський ${ }^{2}$, Оксана Вовк ${ }^{1}$ \\ ${ }^{1}$ Наиіональний авіачійний університет, anna.yakovlieva@nau.edu.ua, \\ ${ }^{2}$ Факультет будови машин і авіації Жешувського технологічного університету, sboichen@prz.edu.pl \\ РОЗРОБЛЕННЯ АЛЬТЕРНАТИВНИХ АВІАЦІЙНИХ ПАЛИВ, МОДИФІКОВАНИХ БІОДОБАВКАМИ НА ОСНОВІ РИЖІЕВОЇ ОЛІЇ}

Стаття присвячена розробленню та вивченню фізико-хімічних та експлуатаційних властивостей нових альтернативних авіаційних палив, модифікованих біодобавками на основі рижієвої олії. Проаналізовано сучасний стан навколишнього середовища, а також вплив авіаційної промисловості на навколишнє середовище. Під час дослідження було вивчено такі фізико-хімічні властивості зразків палив: густина, в'язкість, фракційний склад, теплота згоряння, змащувальна здатність, корозійна активність та температура кристалізації. Встановлено, що властивості біодобавок істотно відрізняються від властивостей авіаційних палив. В результаті проведеної роботи розроблено комплексну порівняльну характеристику фізико-хімічних та експлуатаційних властивостей та показників якості авіаційних палив, біодобавок на основі рижієвої олії та зразків сумішевих авіаційних палив.

Ключові слова: авіаційне паливо, альтернативне паливо, біопаливо, біодобавка, модифікування, рижієва олія, фізико-хімічні властивості.

\section{PЕФЕРАТ}

Анна Яковлева ${ }^{1}$, Сергей Бойченко ${ }^{2}$, Казимир Лейда ${ }^{2}$, Хуберт Кужевский ${ }^{2}$, Оксана Вовк ${ }^{l}$

${ }^{1}$ Национальный авиационный университет, anna.yakovlieva@nau.edu.иa,

${ }^{2}$ Факультет конструкции машин и авиации Жешувского технологического университета, sboichen@prz.edu.pl

РАЗРАБОТКА АЛЬТЕРНАТИВНЫХ АВИАЦИОННЫХ ТОПЛИВ, МОДИФИЦИРОВАННЫХ БИОДОБАВКАМИ НА ОСНОВЕ РЫЖИКОВОГО МАСЛА

Настоящая статья посвящена разработке и изучению физико-химических и эксплуатационных свойств новых альтернативных авиационных топлив, модифицированных биодобавками на основе рыжикового масла. Проведено анализ современной состояния окружающей среды, а также влияния 
авиационной промышленности на окружающую среду. В ходе исследования были изучены следующие физико-химические свойства образцов топлив: плотность, вязкость, фракционный состав, теплота сгорания, смазывающая способность, коррозионная активность и температура кристаллизации. Было установлено, что свойства биодобавок значительно отличаются от свойств авиационного топлива. В результате работы была разработана комплексная сравнительная характеристика физикохимических и эксплуатационных свойств и качественных показателей авиационного топлива, биодобавок на основе рыжикового масла и образцов смесевых авиационных топлив.

Ключевые слова: авиационное топливо, альтернативное топливо, битопливо, биодобавка, модифкация, рижиковое масло, физико-химические свойства.

\author{
ABSTRACT \\ Anna Iakovlieval ${ }^{l}$,Sergii Boichenko ${ }^{2}$, Kazimierz Lejda ${ }^{2}$, Hubert Kuszewski ${ }^{2}$, Oksana Vovk ${ }^{1}$ \\ ${ }^{I}$ National Aviation University, anna.yakovlieva@nau.edu.ua, \\ ${ }^{2}$ Faculty of Mechanical Engineering and Aeronautics of Rzeszow University of Technology, \\ sboichen@prz.edu.pl \\ DEVELOPMENT OF ALTERNATIVE JET FUELS MODIFIED \\ WITH CAMELINA OIL BIO-ADDITIVES
}

This paper is devoted to the development and study of physical-chemical and exploitation properties of new alternative jet fuels modified with camelina oil bio-additives. The current condition of environment is analyzed as well as the impact of aviation industry on the environment. During the study the following physical-chemical properties were investigated: density, viscosity, fractional composition, heat of combustion, lubricity, corrosiveness and freezing point. It was found that properties of bio-additives are significantly different from properties of jet fuels. As a result of the work, the complex comparative characteristic of physical-chemical and exploitation properties and quality parameters of jet fuel, camelina oil bio-additive and blended jet fuel samples, was developed.

Key words: jet fuel, alternative fuel, biofuel, bio-additive, modification, camelina oil, physicalchemical properties.

\title{
REFERENCES
}

1. Chuck C.J. The compatibility of potential bioderived fuels with Jet A-1 aviation kerosene / C.J. Chuck, J. Donnelly // Applied Energy. - 2014. - Vol. 118. - P. 83-91.

2. Case Study of Alternative Jet Fuel Production with Bio-additives from Plant Oils in Ukraine and Poland. / [A.Yakovlieva, S.Boichenko, O.Vovket al.]. // Advancesin Sustainable Aviation / Tahir Hikmet Karakoç, C. Ozgur Colpan, Yasin Şöhret (eds). - Cham: Springer International Publishing, 2018. - Chapter 4. - P. 41-63.

3. Influence of Rapeseed Oil Ester Additiveson Fuel Quality Index for Air Jet Engines / [A.V.Yakovlieva, S.V.Boichenko, K.Leida, et al.]. // Chemistry and Technology of Fuels and Oils. - 2017. - Vol. 53. - Iss. 3. - P. 308-317.

4. Iakovlieva A.V. Potential of camelina as a raw material for producing of modified aviation fuel components / A.V. Iakovlieva, S.V. Boichenko, A.V. Bondaruk // Scientific technologies. - 2016. - №. 1(29). - P. 123-127.

5. Influence of rapeseed oil esters jetfueladditives on some indicators of its quality / [A. Iakovlieva, O. Vovk, S. Boichenko et al.]. // Monografia «Systems and means of motortransport». Selected problems. Seria: Transport. - Rzeszow. - № 6.-2015. - P. 167-173.

6. Engineering basesof aviation chemmotology / [L.S. Yanovsky, N.F. Dubovkin, F.M. Galimov et al.]. - Kazan: Edition of Kazan.University, 2005. - 714 P.

7. Alternative jet fuels: problems and prospects / [L.S. Yanovsky, E.P. Fedorov, N.I. Varlamova et al.]. // Proceedings of the National Aviation University. - 2009. - No 1. - P. 108-112.

8. Comparative characteristics of low-temperature properties of jet fuels modified with bio-additives / S. Boichenko, K. Lejda, A. Yakovlieva, O. Vovk // International Automotive Conference (KONMOT2018). IOPConf. Series: Materials Science and Engineering. - 2018. - 421. - 032003.

9. Hileman J.I. Alternative jet fuel feasibility / J.I.Hileman, R.W.Stratton // Transport Policy. - 2014. - Vol. 34. - P. 52-62. 